\title{
RELIEF FROM DELINOUENCY PENALTIES: THE INTERNAL REVENUE CODE
}

\author{
By Herbert W. Reisner +
}

The Internal Revenue Code provides for the imposition of "additions to the tax" in cases of delinquency, negligence and fraud. Such additions, or penalties, are civil incidents of the assessment and collection of the tax. ${ }^{1}$ The so-called delinquency penalties are added to the $\operatorname{tax}$ in case of any failure to file required $\operatorname{tax}^{2}$ returns and in case of any failure to file a declaration or to pay an installment of estimated tax within the prescribed time, unless it is shown that such failures are due to "reasonable cause" and not due to "willful neglect." This article deals primarily with these basic provisions for relief from delinquency penalties.

\section{Statutory History}

The principal delinquency penalties are imposed under section 291 in cases of income and additional income taxes (including the personal holding company surtax and the excess profits tax ${ }^{3}$ and under sec-

$\dagger$ A. B., Haverford, 1931; LI.B., University of Pennsylvania, 1934; member, Pennsylvania Bar; former member of legal staff of The Tax Court of the United States.

1. "Additions to the tax" are separate liabilities and may be imposed concurrently. Delinquency and fraud penalties: Hoefle v. Commissioner, $114 \mathrm{~F}$. $2 \mathrm{~d} 713$ (6th Cir. 1940) ; Pincus Brecher, 27 B. T. A. 1108 (1933). Delinquency and negligence penalties: Vahram Chimchirian, 42 B. T. A. 1437 (1940), aff'd, 125 F. 2d 746 (D. C. Cir. 1942). The principle stated in the text was relied upon by the Supreme Court in holding that an addition to income tax for fraud was not barred under the doctrine of double jeopardy by an acquittal on an indictment growing out of the same offense. Helvering v. Mitchell, 303 U. S. 391 (1938); cf. Hoefle v. Commissioner, supra, and Henry H. Epstein, 34 B. T. A. 925 (1936), in which civil penalties were inposed in addition to criminal penalties for the same act or omission. The same principle was relied upon in ruling that additions to the tax do not abate with death. G. C. M. 22326, 1940-2 CuM. BuLL. 159, revoking a contrary ruling; followed in Estate of Charles Louis Reimer, 12 T. C. No. 121 (1949), wherein the addition was treated as an indemnity for the loss resulting from a wrongful act or tort committed by the taxpayer.

2. "Additions to the tax" have no application to information returns. However, criminal penalties may be imposed under INT. REV. CODE $\$ 145$, relating to returns for income tax purposes. See also INT. Rev. CoDE \$\$340, 3793(b). Civil and criminal penalties are provided under $\$ 894(\mathrm{~b})$ for estate tax purposes. Criminal penalties are provided under $\$ 1024$ for gift tax purposes.

3. Section 291 is applicable to returns required by Chapter 1 (income tax) and by general references it is made applicable to returns required by Chapter 2 (additional income taxes) of the Internal Revenue Code. A personal holding company is deprived of the right to a deficiency dividend credit under $\$ 506(f)$ in case of failure to file a return required under Subchapter A of Chapter 2 within the time prescribed "unless it is shown that such failure to file is due to reasonable cause and not due to willful neglect." Section 291 applies to a withholding agent under $\$ \$ 143$ and 144. A. C. Monk \& Co., Inc., 10 T. C. 77 (1948); Kimble Glass Co., 9 T. C. 183, 191 (1947); P. D. Bowlen, 4 T. C. 486 (1944); St. Francis Hospital, 42 B. T. A. 1004 (1940), aff'd, 125 F. 2 d 553 (D. C. Cir. 1942). Cf. S. M. 1334, 2 CuM. Buls. 
tion 3612 (d) (1) in cases of estate and gift taxes. ${ }^{4}$ Penalties are imposed under section 294 (d) (1) (A) and (B) in cases of estimated taxes. $^{5}$ These three sections of the Code contain similar provisions for relief which are traceable to a statute of Civil War days, as amended by the Revenue Act of 1916.

The Revised Statutes provided in section 3176 a penalty of 50 per cent in case of refusal or neglect to file any required return (or list) "except in cases of sickness or absence." "This section was amended by the Revenue Act of 1916 which provided that the penalty would not be added when a return was filed late but voluntarily "and it is shown that the failure to file it was due to a reasonable cause and not to willful neglect." 7 The Revenue Act of 1918 reduced the penalty to 25 per cent. $^{8}$ The Revenue Act of 1935 introduced the current penalty rates of 5 per cent of the tax for each 30 days or fraction thereof during which the failure to file a required return continues, not exceeding 25 per cent in the aggregate. ${ }^{9}$

The penalty was mandatory under the pre-1936 Acts if no return was filed by the taxpayer, $i$. $e$, the penalty could be lifted for reasonable cause only when the taxpayer filed a late return. ${ }^{10}$ The require-

229 (1920). Section 291 also applies where an executor or administrator disaffirms a joint return filed by a surviving spouse. See H. R. REP. No. 1274, 80th Cong., 2nd Sess. (1948), 1948-1 CuM. Bull. 283 in connection with the Revenue Act of 1948 , \& 303(4), 62 STAT. 110 (1948).

4. Section 3612 (d) (1) is made applicable to returns required by Chapter 3 (estate $\operatorname{tax}$ ) and Chapter 4 (gift tax) through specific cross-references under INT. REV. CODE $\$ \S 894$ and 1018, respectively. This results in the application of the pre1936 rule, note 10 infra, to estate and gift tax cases, note 11 infra.

5. Added to the Code by Act of Feb. 25, 1944, Revenue Act of 1943, §118(a), 58 Stat. 37 (1943); amended by Act of May 29, 1944, Individual Income Tax Act of 1944, § 13(b), 58 STAT. 244 (1944).

6. Revised Statutes, \& 14, 13 STAT. 226 (1864). The component statutes and the amendments to $\$ 3176$ of the Revised Statutes are referred to in the historical note under 26 U. S. C. A. $\$ 3612$. The provisions in effect prior to 1916 were construed in L. O. 1060, 4 CuM. Bunt. 318 (1921).

7. Revenue Act of 1916, \$16, 39 STAT. 773 (1916).

8. And provided that the penalty would be added in case of any failure to file a return in time "except that when a return is filed after such time and it is shown that the failure to file it was due to a reasonable cause and not to willful neglect, no addition shall be made to the tax." Revenue Act of 1918, $\$ 1317,40$ STat. 1147 (1919).

9. Revenue Act of 1935, §406, 49 Stat. 1027 (1935). See Sen. Rep. No. 1240 74th Cong., 1st Sess. 12 (1935), 1939-1:2 CuMr. BuLL. 651, 658; and CoNf. Rep. No. 1885, 74th Cong., 1st Sess. 13 (1935), 1939-1:2 Cum. Bull. 660, 666.

10. Commissioner v. Lane-Wells Co., 321 U. S. 219 (1944). See cases collected in 10 MERTENS, LAW OF FEDERAL INCOME TAXATION $\$ 55.21 \mathrm{n} .71$ (1942). In Helvering v. Boekman, 107 F. 2d 388 (2d Cir. 1939), reversing on other grounds 38 B. T. A. 541 (1938), a return filed by the Commissioner was held not to be a compliance with the statute. Cf. J. S. F. Crayton, 11 B. T. A. 1375, 1381 (1928); John B. Nordholt, 4 B. T. A. 509, 514 (1926); see G. C. M. 17478, 1937-1 CuM. Bull. 122, revoked by G. C. M. 24110, 1944 CuM. Bulc. 521. In Taylor Securities, Inc., 40 B. T. A, 696 (1939), returns filed by the taxpayer, after filing its petition but before hearing, were held to be insufficient to avoid the mandatory operation of the statute. However, the Board also said there was no evidence for determining whether the delinquencies were due to reasonable cause. This decision was followed in Blenheim Co., Ltd., 42 B. T. A. 1248, 1254 (1940), aff'd, 125 F. 2d 906 (4th Cir. 1942). 
ment of filing a late return has been retained in Code section 3612 (d) (1), an administrative provision which is also applicable to estate and gift tax delinquencies. ${ }^{11}$ However, the 1936 Act ${ }^{12}$ eliminated the requirement of filing a late return in cases of income and additional income taxes. ${ }^{13}$ The language of the 1936 Act now appears in section 291 of the Code with minor technical changes.

Section 294 (d) (1) of the Code, as added by the Revenue Act of 1943 , also provides penalties of 5 to 10 per cent on installments of estimated taxes for failure to file a declaration or for failure to pay an installment of such taxes within the prescribed time, in either case "unless such failure is shown to the satisfaction of the Commissioner to be due to reasonable cause and not to willful neglect." 14

Throughout the history of these changes and additions the committees of the Congress have never commented in their reports upon the provisions for relief from delinquency penalties. There is no apparent reason why mandatory penalties ( $i . e$. , in the absence of filing a late return) were allowed to survive for estate and gift tax purposes after such penalties had been discontinued for income tax purposes.

\section{"Reasonable Cause"}

The basic ground for relief from delinquency penalties is a showing that the delinquencies were due to "reasonable cause." This is a question of fact. ${ }^{15}$

The oldest test of "reasonable cause" is to determine whether the delinquent taxpayer "exercised ordinary business care and prudence."

11. As to gift taxes see Charles Guzy, P-H 1949 TC Menr. Dec. SERv. II 49,182 (1949); William Fleming, 3 T. C. 974 (1944), aff'd, 155 F. 2d 204 (5th Cir. 1946), without discussion of penalty issue; Chas. F. Roeser, 2 T. C. 298 (1943) ; see Carlton B. Overton, 6 T. C. 304, 313 (1946), aff'd, 162 F. 2d 155 (2d Cir. 1947). In Estate of Henry Wilson, 2 T. C. 1059 (1943), the question of reasonable cause was discussed even though the estate filed no return. Cf. note 10 sitpra.

12. Revenue Act of $1936, \S 291,49$ STAT. 1727 (1936). Under this section the penalty is added in case of any failure to file a required return in time "unless it is shown that such failure is due to reasonable cause and not due to willful neglect."

13. Commissioner v. Lane Wells Co., 321 U. S. 219 (1944). On remand the penalty for 1936 was approved in accordance with a stipulation of the parties. See also Estate of Frederick C. Kirchner, 46 B. T. A. 578 (1942), in which the Board clarified the 1936 rule where no return was filed. The Commissioner's regulations were not amended until five years after the rule had been changed by the statute. T. D. 5058, 1941-2 Cum. Bull. 156. In Elrod Slug Casting Machine Co., P-H 1948 TC MEM. DEC. SERv. II 48,041 (1948), the pre-1936 rule appears to have been followed in an income tax case. See also Currier Farms, Inc., P-H 1948 TC MEM. DeC. Serv. II 48,188 (1949).

14. Section 294(d) (1) (A) and (B). See note 5 supra. Albert T. Felix, 12 T. C. No. 124 (1949).

15. Commissioner v. Lane-Wells Co., 321 U. S. 219 (1944), citing Dobson v. Commissioner, 320 U. S. 489 (1944). Cf. Hatfried, Inc. v. Commissioner, $162 \mathrm{~F}$. 2d 628 (3rd Cir. 1947), with P. Dougherty Co. v. Commissioner, 159 F. 2d 269 (4th Cir. 1946), cert. den. 331 U. S. 838 (1947). The penalty issue was tried by a jury in Reliance Feed \& Grain Co. v. Shaughnessy, 84 F. Supp. 389 (N. D. N. Y. 1949). 
The business prudence test was employed first by the Commissioner in the revised Regulations applicable to the Revenue Act of $1916 .{ }^{16}$ As modified by the Regulations applicable to the 1921 Act, ${ }^{17}$ this test has appeared in all of the Regulations relating to the income tax substantially as follows: ${ }^{18}$

. . If the taxpayer exercised ordinary business care and prudence and was nevertheless unable to file the return within the prescribed time, then the delay is due to a reasonable cause.

The Regulations have not been cited in many cases, probably because the regulatory test implies that all taxpayers must have been not only prudent but also "unable" to file returns in order to qualify for relief. The current judicial view is that "reasonable cause means nothing more than the exercise of ordinary business care and prudence." 19 In Spies' v. United States, ${ }^{20}$ a criminal case, the Supreme Court said of all penalties (including delinquency penalties):

... It is not the purpose of the law to penalize frank difference of opinion or innocent errors made despite the exercise of reasonable care. Such errors are corrected by the assessment of the deficiency of $\operatorname{tax}$ and its collection with interest for the delay.

Relief from delinquency penalties is not restricted to cases of prudent taxpayers who were also unable to file returns. Subsequent discussion will show, for example, that a belief that no return was required, founded upon a reasonable basis, is a "reasonable cause" within the meaning of the statute.

16. U. S. Treas. Reg. 33 (Revised), art. 54 \292 (1918), provided as to individuals: "Reasonable cause", for the purpose of this article of the regulations, is held to be such a condition of fact as had the taxpayer in default exercised ordinary business" care and prudence it would have been impracticable or impossible for him to have filed return on the prescribed time." Cf. id., art. 54 \ 644 (as to corporation).

17. U. S. Treas. Reg. 62, art 1004 (1922) (relating to Income Tax and War Profits and Excess Profits Tax).

18. U. S. Treas. Reg. $111 \$ 29.291-1$ (1943). The booklet issued by the Bureau of Internal Revenue, Your FEDERAL INCONE TAX II (1948), states that "reasonable cause does not include ignorance of the law, forgetfulness, carelessness, oversight, or any other trivial cause. The cause for late filing must be substantial." This is a fair but incomplete statement of the case law.

19. Orient Investment \& Finance Co. v. Commissioner, 166 F. 2d 601 (D. C. Cir. 1948); Hatfried, Inc. v. Commissioner, 162 F. 2d 628 (3rd Cir. 1947); Southeastern Finance Co. v. Commissioner, 153 F. 2d 205 (5th Cir. 1946); Girard Investment Co. v. Commissioner, 122 F. 2d 843 (3rd Cir. 1941), cert. denied, 314 U. S. 699 (1942) ; Nathan Blum, 5 T. C. 702 (1945); cf. Charles E. Pearsall \& Son, 29 B. T. A. 747 (1934) in which it was said: "Reasonable cause'. . . means such a cause as would prompt an ordinarily, intelligent and prudent business man to have so acted under similar circumstances."

20. 317 U. S. 492, 496 (1943). 
The statute expressly places a burden on the taxpayer to show that the delinquency was due to "reasonable cause" and not due to "willful neglect." The books are full of cases in which penalties have been approved for lack of any evidence whatsoever, but if the taxpayer has discharged his burden of showing "reasonable cause" the chances are that the same evidence also shows the absence of "willful neglect." ${ }^{21}$ The converse, however, is not true. The absence of "willful neglect" is not alone sufficient to avoid the imposition of delinquency penalties. ${ }^{22}$

In some delinquency cases the principal question is whether a return filed within the prescribed time was a sufficient return. ${ }^{23}$ This question goes beyond the scope of the present discussion. If the return was insufficient the penalty is mandatory under section 3612 (d) (1) as to gift and estate taxes but it is not mandatory as to income taxes under section 291 of the Code. If the return was sufficient (and filed within the prescribed time) the question of "reasonable cause" is of course moot. Similarly, the question of "reasonable cause" is moot in cases where no return was required, ${ }^{24}$ or where no tax was due. ${ }^{25}$

The leading cases involving what the taxpayer must show to establish "reasonable cause" will be discussed in the following pages. The main topics deal respectively with delinquencies caused primarily by (1) taxpayers, (2) their agents and (3) their advisors.

\section{Delinguencies Caused by Taxpayers}

There are so few reported cases of delinquencies caused by events beyond the control of prudent taxpayers that such cases are considered here under a broad title. It is very important, however, to distinguish between the delinquencies caused by taxpayers who claim that they were unable to file a required return in time, and those who claim a belief that no return was required and filed none. The business prudence test should be applied to both groups. Paradoxically, although

21. In P. Dougherty Co. v. Commissioner, 159 F. 2d 269, 273 (4th Cir. 1946), cert. destied, 331 U. S. 838 (1947), it was said that "one who searches for the motives underlying human conduct in a particular field is on uncertain ground when he tries to determine where willful neglect ends and reasonable cause begins" (Italics supplied).

22. See George S. Van Schaich, Supt. of Insurance, 32 B. T. A. 736, 744 (1935), aff'd, 83 F. 2d 940 (2d Cir. 1936); Charles E. Pearsall \& Son, 29 B. T. A. 747 (1934). In Estate of Samuel Goldstein, P-H 1947 TC MEM. DEc. SERv. đI 47,220 (July 30, 1947) the court said: "There could be neglect without willfulness and by the same token there could be lack of reasonable cause, even though no williul intent was present."

23. What constitutes a sufficient return is discussed in 10 MERTENs, LAw of FEDERAL INCOME TAXATION $\llbracket 55.22$ and notes (1942). Cf. id. at $\{57.12$ et seq.

24. Minnesota Mortuaries, Inc., 4 T. C. 280, 286 (1944); Pacific Northwest Finance Corporation, 3 T. C. 498,507 (1944).

25. Robert Hughes \& Co. v. Commissioner, 109 F. 2d 720 (8th Cir. 1940) ; 415 South Taylor Building Corp., 2 T. C. 184, 193 (1943). 
this test is applied by the Regulations only to the first group, it has been more frequently applied by the courts to the second group.

\section{Inability to File a Required Return}

The Regulations have always excused the inability to file a required return in time if the taxpayer exercised ordinary business care and prudence in an attempt to file on time. ${ }^{26}$ In a few cases delinquency penalties were lifted by the Board of Tax Appeals (now Tax Court) on meager evidence of the impossibility of filing returns. ${ }^{27}$ The Tax Court has given relief from a delinquency penalty where a taxpayer showed that it was involved in extensive litigation and was unable to marshall its records in time for the preparation of its return. ${ }^{28}$ The delay in filing returns has been held not due to reasonable cause, however, where the task of preparing the returns was clearly burdensome but not impossible. ${ }^{29}$

The most recent cases require the highest degree of proof. In Nirosta Corporation, ${ }^{30}$ which is perhaps the extreme example, the taxpayer failed to file required personal holding company returns for the years 1938 through 1942. Deficiencies were determined and penalties were added by the Commissioner for 1938, 1939 and 1942; all were paid except the penalty for 1942 . The taxpayer contended that it was impossible to determine the ownership of more than half of its stock which had been held successively by a German, a Dutch and a Swiss company, and finally had been seized by the Alien Property Custodian. Although the Tax Court took judicial notice that the United States was at war with Germany during the years 1942 and 1943, it reasoned as follows:

. . there was no evidence introduced, nothing stipulated, and nothing in the facts of which this Court may take judicial notice which would show the impossibility of procuring the information which the taxpayer deemed necessary before it could file a personal holding company tax return. The fact that this country and Germany were at war in 1942 and 1943 undoubtedly would

26. U. S. Treas. Reg. $111 \$ 29.291-1$ (1943). See notes 16,17 and 18 supra.

27. In Philad Co. of Delaware, 47 B. T. A. 565, 570 (1942), a taxpayer was "unable to determine the correct amount of income to be accrued" but apparently did not show why it was unable to do so. In Millard D. Olds, 15 B. T. A. 560, 564 (1929), aff'd without discussion of penalty, 60 F. 2d 252 (6th Cir. 1932), a taxpayer who was a partner delayed in filing his individual return because he was unable to obtain a partnership return form.

28. Hendrick Ranch Royalties, P-H 1943 TC MEM. DEC. SERv. 1143,137 (1943).

29. George S. Van Schaick, Supt. of Insurance, 32 B. T. A. 736,744 (1935), aff'd without discussion of penalty, 83 F. 2d 940 (2d Cir. 1936); Erie Forge Co., P-H 1945 TC MEM. DEc. SERv. I 45,384 (1945), aff'd, 167 F. 2d 71 (3rd Cir. 1948); Nathan Blum, 5 T. C. 702, 712 (1945) (applied the test of ordinary business care and prudence).

30. 8 T. C. 987,990 (1947). Cf. Oak Commercial Corp., 9 T. C. 947, 955 (1947), aff'd as modified, 172 F. $2 \mathrm{~d} 896$ (2d Cir. 1949) (taxpayer abandoned penalty issue). 
make the procurement of such information difficult, but this Court can not take judicial notice that the procurement of such information was impossible and the taxpayer has given us no evidence that it even made any attempt during 1942 and 1943 to procure this information.

The court approved the penalties without mention of the business prudence test.

Although sickness and absence were once statutory grounds for relief, ${ }^{31}$ mere absence is no longer an excuse. ${ }^{32}$ Delinquencies have been held to be due to reasonable cause, where an executrix, as well as her attorney, had incapacitating illnesses. ${ }^{33}$

\section{Belief That No Return Was Required}

The American Bar Association recently proposed an amendment of the statute to provide that "a belief that no return was required, founded upon a reasonable basis, shall be deemed reasonable cause." ${ }^{34}$ This is a concise restatement of the current case law. The real problem in most cases is to show that the delinquent taxpayer had a basis for his belief, ${ }^{35}$

Many cases hold that mere ignorance of the law is not a reasonable cause for delinquency. ${ }^{36}$ Many others hold that a mere belief,

31. See note 6 supra.

32. John Balestreri, 47 B. T. A. 241, 246 (1942) ; see Paul E. Reinhold, P-H 1948 TC Men. Dec. Serv. I 48,196 (1948); M. \& F. Holding Corp., 26 B. T. A. 504, 508 (1932) ; but see Bankers Dairy Credit Corp., 26 B. T. A. 886, 888 (1932). 33. Estate of Frederick C. Kirchner, 46 B. T. A. 578, 582 (1942); Estate of K. Threefoot, 9 B. T. A. 499 (1927) (facts showed sickness).

34. See pamphlet by Section of Taxation, American Bar Association, Reconsmendations for Changes in Federal Internal Revenue Code 15 (1947). The recommendation includes other provisions which would authorize the Commissioner to modify the effects of penalties under $\$ \S 291$ and $506(f)$ of the Internal Revenue Code.

35. The Section of Taxation incorrectly states that the problem is as follows: "Considerable hardship has resulted from decisions of the courts holding that the imposition of penalties is mandatory even in cases where taxpayers honestly believe that no return was due, such as where corporations honestly believe themselves not to be personal holding companies which failed to file form $1120-\mathrm{H}$, where corporations honestly believe themselves not to be subject to excess profits taxes and therefore fail to file excess profits tax returns, etc. The courts have expressed sympathy for the taxpayers but have stated that the remedy lies in the hands of Congress. In the case of a personal holding company, failure to file return not only results in the 25 per cent penalty under section 291 (a) but also deprives the corporation of the right to declare deficiency dividends (section 506(f)), which is often much more costly than the 25 per cent penalty." Ibid. This comment seems to be based on the decision in O'Sullivan Rubber Co. v. Commissioner, 42 B. T. A. 721 (1940), aff'd, 120 F. 2d 845 (2nd Cir. 1941), which involved the Revenue Act of 1934 and in which it was held that the penalty for failure to file any personal holding company return was mandatory. See note 10 supra. Under subsequent Revenue Acts and under the Internal Revenue Code the penalty is no longer mandatory. Note 13 supra.

36. Southeastern Finance Co., 4 T. C. 1069, 1087 (1945), aff'd, 153 F. 2d 205 (5th Cir. 1946) ; Tarbox Corp., 6 T. C. 35 (1946); see also Frank W. Ross, 44 B. T. A. 1,17 (1941) ; Samuel Goldwyn, Inc., Ltd., 43 B. T. A. 1086, 1089 (1941); Chas. E. Pearsall \& Son, 29 B. T. A. 747, 749 (1934) ; Joseph G. Hitner, P-H 1943 TC MeN. Dec. Serv. \43,081 (1943); Balfour, Williamson \& Co., Itd., P-H 1943 TC Mear. DeC. Serv. T43,157 (1943). 
contrary to the law, is not a reasonable cause for delinquency. ${ }^{37}$ In such cases the taxpayer has not shown any basis for testing the reasonableness of his belief that no return was required. In $W$ est Side Tennis Club v. Commissioner ${ }^{38}$ it was said:

We regret that the imposition of this penalty which the Board has affirmed is necessary, for the liability of the club to taxation was by no means clear. Nevertheless the burden of establishing reasonable cause was upon the taxpayer and it has not shown a timely effort to get advice or to secure a ruling and has rested its case on the finding of the Board that the officers and directors believed that it was exempt. But this, without more, was not sufficient. As the Board correctly said: "We do not know the steps taken by petitioner to ascertain its status as a taxpayer, and zerithout knowledge of the basis for the belief of its officers and directors that it was exempt from tax we are in no position to test the reasonableness of the conclusion." [Italics supplied]

On the other hand, in Fairfax Mutual Wood Products Co. ${ }^{39}$ the taxpayer successfully claimed relief from the penalty on the basis of its belief that it was exempt from excess profits tax as a personal service corporation under section 725 (a) of the Code, as amended. A statement was attached to its income tax return which explained why it considered itself exempt under the statute. It further elected to be so classified and stated that its stockholders had included their share of undistributed profits in their individual returns. The Tax Court held as follows :

. ... We do not think that we are warranted in holding that a corporation claiming the benefits of section 725 , supra, does so

37. Cedarburg Canning Co. v. Commission, 149 F. 2d 526 (7th Cir. 1945), affirming P-H 1944 TC MEM. Dec. SeRv. II 44,095 (1944) ; Burford Oil Co., 4 T. C. 613, 618 (1945), aff'd, 153 F. 2d 745 (5th Cir. 1946); Rafael Sabatini, 32 B. T. A. 705, 713 (1935), aff'd on penalty issue, 98 F. 2d 753 (2d Cir. 1938), in which the circuit court said, "The taxpayer may well have believed that he was liable for no taxes and yet have had no reasonable cause for not filing returns." Id. at 756 . In many cases it is impossible to tell from the report whether the court thought that there was no basis, or that there was not a reasonable basis, for the taxpayer's belief. See Home Builders Lumber Co., P-H 1946 TC MEM. DEc. SERv. $\mathbb{1}$ 46,282 (1946), aff'd, 165 F. 2d 1009 (5th Cir. 1948); Philip Suetter, P-H 1946 TC Mem. DEC. SERv. If 46,247 (1946) ; P. D. Bowlen, 4 T. C. 486, 494 (1944); Central Appraisal Bureau, P-H 1942 B. T. A. MEM. DEc. SERv. II 42,235 (1942); R. Simpson \& Co. 44 B. T. A. 498. 501 (1941); aff'd, 128 F. 2 d 742 (2d Cir. 1942), cert. dismissed, 321 U. S. 225 (1944).

38. 111 F. 2d 6, 9 (2d Cir. 1940), afirming 39 B. T. A. 149, 160 (1939), cert. denied, 311 U. S. $674(1940)$. This case followed Jockey Club, 30 B. T. A. 670,678 (1934), aff'd, 76 F. 2d 597 (2d Cir. 1935), on the principal issue but distinguished that case on the penalty issue because there the taxpayer filed blank returns within the time prescribed by law and claimed exemption. It is doubtful whether the Jockey Chob case is good law on the penalty issue today. See Automotive Electric Association, 8 T. C. 894, 902 (1947), aff'd revithout discussion of penalty issue, $168 \mathrm{~F} .2 \mathrm{~d} 366$ (6th Cir. 1948).

39. 5 T. C. 1279,1283 (1945). 
at its peril. An election, in good faith, based upon an analysis of its own business should not, we think, open the way to the imposition of the penalty if such election be an erroneous one. Petitioner did not willfully neglect to file an excess profits tax return, but advisedly refrained from filing in a reasonable belief that none was required of it. It is not the purpose of the law to penalize frank difference of opinion or innocent errors made despite the exercise of reasonable care. Such errors are corrected by the assessment of the deficiency of tax and its collection with interest for the delay. Spies v. United States, 317 U. S. 492. The imposition of the delinquency penalty under section 291 (a) is not justified.

Other cases involve the narrower question whether the basis for the taxpayer's belief was reasonable.

In $P$. Dougherty $\mathrm{Co}^{40}$ the taxpayer did not file an excess profits tax return because its officers believed that it did not have any excess profits net income for the taxable year. It filed an income and declared value excess profits tax return in which it reported a net loss resulting from depreciation and loss deductions. No excess profits tax return was required under the statute if the excess profits net income was not greater than $\$ 5,000$. The Tax Court held that some of the adjustments made by the Commissioner were proper for income and excess profits tax purposes but that "It is yet to be determined under Rule 50 computation, in accordance with our opinion herein, whether there will be any excess profits tax due for the taxable year." The Court also held that the penalty was properly added by the Commissioner because "there is no proof whatever that the good faith of the petitioner or its belief that it had no excess profits tax net income was based on reasonable grounds." Five judges, dissenting, took the view that the errors made by the taxpayer in its income tax return were innocently made. The Circuit Court affirmed the majority decision because it thought that the question was one of fact, peculiarly within the province of the Tax Court.

In Economy Savings \& Loan Co. ${ }^{41}$ the taxpayer was a building and loan association which kept its books and filed its returns on a fiscal

40. 5 T. C. 791, 800 (1945), aff'd, 159 F. 2 d 269 (4th Cir. 1946), cert. denied, 331 U. S. 838 (1947), followed in Home Guaranty Abstract Co., 8 T. C. 617, 622 (1947); Donald V. Smith, P-H 1947 TC Men. Dec. SERv. II 47,137 (1947). Cf. Wass \& Stinson Canning Co., P-H 1945 TC Mer. Dec. Serv. \4 45,350 (1945); Ardbern Co:, Itd., 41 B. T. A. 910, 928 (1940), aff'd on penalty issue, $120 \mathrm{~F}, 2 \mathrm{~d} 424$ (4th Cir. 1941) ; Nathan Stein, 40 B. T. A. 848, 855 (1939), aff'd without discussion of penalty, 115 F. 2d 468 (4th Cir. 1940); T. H. Symington \& Son, Inc., 35 B. T. A. 711,739 (1937). Contra: Fajardo Sugar Co. of Porto Rico, 20 B. T. A. 980, 989 (1930) (Board said the taxpayer had not been guilty of willful neglect but did not mention reasonable cause). See Herbert Marshall, 41 B. T. A. 1064, 1072 (1940). 41. 5 T. C. 543, 552 (1945), rev'd on penalty issue, 158 F. 2d 472 (6th Cir. 1946), followed in Standard Fruit Product Co., TC Mem. Op. (Aug. 22, 1949). 
year basis ending September 30. It had an exempt status until February 1,1940 , when it changed its method of operation by doing most of its business thereafter with non-shareholders. The principal question was whether its taxable year began in 1939 or 1940, since the Second Revenue Act of 1940 imposed new income tax rates and the excess profits tax for years beginning after 1939. The taxpayer filed an income tax return for the year ended September 30, 1940, which was prorated for the last eight months and computed under the rates imposed by the Revenue Act of 1938 . It did not file any excess profits tax return. Its officers believed that its taxable year began in 1939 and therefore that no return was required. The Tax Court held that the taxable year began in 1940 and sustained the taxes under the 1940 Act. It also sustained the penalty on the theory that there was no evidence offered in support of the taxpayer's belief that no return was required. The Circuit Court reversed the latter decision. It said: ${ }^{\mathbf{4 2}}$

. The Tax Court sustained the Commissioner's assessment, with three members dissenting. The court held that petitioner had not shown its failure to file the required return was due to reasonable cause. We think the record conclusively shows that petitioner was not guilty of any wilful neglect in failing to file the return, and that it just as conclusively shows that the taxpayer did have a reasonable cause for its failure to make the return. The record discloses that petitioner not only believed that the excess profits tax return was not required, but that this belief was founded upon reasonable grounds, which are cogently set forth in the forceful brief filed in its behalf.

The excess profits tax did not accrue until December 31 , 1939, and there were substantial grounds for the conclusion that petitioner's taxable year began on October of that year.' While these considerations were not accepted by us, they nevertheless do afford a reasonable basis for petitioner's contention. Just what constitutes a taxable year or a taxable period within the year has been a matter of much concern and not free from ambiguity . . . so much so in fact, as to require a clarifying amendment (Act Oct. 21, 1942) to Sec. 48 (a) of the Internal Revenue Code.

A taxpayer should not be penalized for making an honest effort upon reasonable grounds to avoid what he in good faith believes to be an unreasonable exaction.

Although the Tax Court had not passed on the question of reasonableness in this case the Circuit Court held that the taxpayer's belief was founded upon a reasonable basis. In the Dougherty case

42. 158 F. 2d 472, 474 (6th Cir. 1946). The Tax Court recently took a similar view in Twin Oaks Co., P-H 1949 TC MeM. DeC. SERv. If 49,067 (1949), wherein it said that the officers of a corporate taxpayer "honestly deemed" a partnership recognizable for tax purposes. 
the Tax Court had found that the taxpayer's belief was not based on reasonable grounds. These cases thus could be distinguished. The significance of both cases to the present discussion is the observance of the principle that a belief, founded upon a reasonable basis, is a reasonable cause for delinquency. ${ }^{43}$

An act or omission of the Commissioner or his agents may give support to the reasonableness of a taxpayer's belief that no return was required. In two recent cases delinquency penalties were lifted where the taxpayers and revenue agents apparently took the same view of similar facts for preceding years, which circumstances afforded a reasonable cause for delinquency during the taxable years. ${ }^{44}$ Penalties have also been lifted where returns of income, held taxable to a grantor, were filed by beneficiaries and accepted over a period of years; ${ }^{45}$ where a taxpayer was "Iulled" into a belief that no return was required by instructions contained upon or given out with tax blanks; ${ }^{48}$ where the Commissioner's ruling that future returns would not be required was changed after the taxpayer had failed to file such returns; ${ }^{47}$ and where the Commissioner had taken an inconsistent position in similar cases. ${ }^{48}$ These circumstances were considered in testing the reasonableness of a belief on the part of the taxpayer; they were not considered as being in the nature of an estoppel against the Commissioner. They would not relieve a taxpayer from the requirement of filing a late return for gift and estate taxes under section 3612 (d) (1) of the Code. ${ }^{49}$ In a recent case, however, relief was denied where the record failed to show that the Commissioner's agent was employed for the purpose of advising taxpayers or that he had such information as would enable him to give reliable advice. ${ }^{50}$

43. The Tax Court's majority and minority opinions in the Dougherty case, note 40 supra, rest upon this principle. The circuit court appears to have applied the Dobson rule to the majority view but it also said: ". . . in a number of decisions of the Tax Court, affirmed by the Courts of Appeals, it has been held that an innocent mistake by a taxpayer which leads him to believe that he is not required to file a return is of itself insufficient to show that his failure was due to reasonable cause within the meaning of the statute. . . "159 F. 2d 269, 273 (4th Cir. 1946). The cases cited in support of this statement all involved a mere belief, without proof of any basis.

44. Hugh Smith, Inc., 8 T. C. 660, 676 (1947), aff'd, 173 F. 2 d 224 (6th Cir. 1949), cert. denied, 337 U. S, 918 (1949), followed in Druggists Supply Corp., 8 T. C. 1343,1351 (1947).

45. William A. Frease, P-H 1944 TC Menr. Dec. Serv. $\llbracket 44,235$ (1944), aff'd per curiam, 150 F. 2d 403 (6th Cir. 1945).

46. Danville Perpetual Bldg. Loan \& Savings Co., P-H 1942 B. T. A. Mes. Dec. SERV. \ 42,438 (1942). (1942)

47. German Hungarian Home Co., P-H 1942 B. T. A. Mens. Dec. Skrv. $\{42,427$

48. Edward S. Moore, P-H 1942 B. T. A. Mear. Dec. Serv. $\int 42,451$ (1942).

49. Cf. Searles Real Estate Trust, 25 B. T. A. 1115, 1120 (1932) (neither the Commissioner nor his agents could waive the requirement of filing a late return under $\$ 3176$ of the Revised Statutes, as amended).

50. Lawrence Block Co., 12 T. C. 366 (1949). 
Reliance upon an order restraining the collector from requiring a return is a reasonable cause for delinquency. ${ }^{51}$ Similarly, a taxpayer would be entitled to rely upon the favorable decision of another case like his own-but not if and after the decision had been reversed.52 If the basis for a taxpayer's belief in his own case has been upheld by a lower court, however, it should be substantial support for the reasonableness of such belief notwithstanding a subsequent reversal..$^{53}$ A novel question has been considered as a proper circumstance for testing the reasonableness of a belief that no return was required. ${ }^{5 \dot{4}}$

These cases raise the interesting question of whether a dissenting opinion on the merits in the taxpayer's own case would afford relief from a delinquency penalty. It should certainly resolve the question of reasonableness but it should not relieve the taxpayer of the burden of showing that the minority position was in fact the basis of his belief. In Palm Beach Trust Company, ${ }^{55}$ the penalty was approved by the Tax Court, notwithstanding dissent, where no evidence was introduced to show the basis for the taxpayer's erroneous belief that a personal holding company surtax return was required. On appeal before the Circuit Court, which avoided this narrow issue, the penalty was lifted because "there was a question debatable in good faith." 56 The Circuit Court did not consider whether the question had been "debated" by the taxpayer prior to the delinquency.

\section{Delinguencies Caused by Agents}

The duty of filing a tax return when due ${ }^{57}$ is a personal duty of the taxpayer himself. He cannot escape that burden by delegating it to an agent. In cases where the taxpayer has delegated the filing

51. J. I. Beale, Jr., P-H 1946 TC Mem. Dec. Serv. đf 46,087 (1946).

52. Hartford-Conn. Trust Co. v. Eaton, 27 F. 2d 530 (2d Cir. 1928), rev'd, 34 F. 2d 129 (2d Cir. 1929) (original return was sufficient under Revised Statutes $\$ 3176$, as amended).

53. Commissioner v. Clarion Oil Co., 148 F. 2d 671 (D. C. Cir. 1945), reversing 1 T. C. 751 (1943), cert. denied, 325 U. S. 881 (1945); but see United States v. Archer, Adm., 174 F. 2d 353, 356 (1st Cir. 1949), reversing 77 F. Supp. 919 (D. Mass. 1948).

54. Agricultural Securities Corp., 39 B. T. A. 1103, 1105 (1939), aff'd per curiam, 116 F. 2d 800 (9th Cir. 1947); William H. Gross, 7 T. C. 837, 848 (1946) (both cases of which involved advisors).

55. 9 T. C. 1060,1068 (1947)

56. 174 F. 2d 527 (D. C. Cir. 1949), cert. denied, - U. S. - (1949).

57 . The regulations provide that a return received after the due date will not be regarded as delinquent if "made and placed in the mails in due course, properly addressed and postage paid, in ample time to reach the office of the collector on or before the due date." U. S. Treas. Reg. 111, \$29.53-4 (1943) ; U. S. Treas. Reg. 105 , § 81.63 (1942) ; U. S. Treas. Reg. 108, \$ 86.22 (1943). Estate of Frederick L. Flinchbaugh, 1 T. C. 653 (1943); Joseph Shalleck, P-H 1942 TC MeMr. Dec. Serv. II 42,684 (1942) ; Capento Securities Corp., 47 B. T. A. 691 (1942), aff'd on other issues, 140 F. $2 d 382$ (1st Cir. 1944). Compare Crude Oil Corp. v. Commissioner, 161 F. 2d 809 (10th Cir. 1947), reversing 6 T. C. 648 (1946), zevith Irvine F. Belser, 10 T. C. 1031 (1948), aff'd, 174 F. 2d 386 (4th Cir. 1949) (petition for certiorari filed). 
of a return to another, his agent's conduct is tested for reasonable cause, and the lack of such cause is charged to the taxpayer. Penalties have been approved where the delinquencies were caused by the ignorance, ${ }^{58}$ forgetfulness, ${ }^{69}$ carelessness, $^{60}$ oversight, ${ }^{61}$ and willful neglect ${ }^{62}$ of agents. Berlin. v. Commissioner ${ }^{63}$ is a frequently cited example. In that case the taxpayer could be relieved from delinquency penalty only by successfully claiming the benefit of an accountant's efforts to procure an extension of time for filing a return. But the accountant had failed to make a bona fide estimate of tax on which the extension was conditioned. The taxpayer's final return was held to be delinquent because the agent's delinquency was without reasonable cause.

\section{Delinguencies Caused by Advisors}

The agency cases considered in the previous section dealt with situations where the taxpayer entrusted another to file his return for him. Those cases must be distinguished carefully from cases in which the taxpayer, relying upon the advice of an attorney or accountant that no return is required, files no return at all, neither personally nor by an agent. We turn now to this latter situation.

Dayton Bronze Bearing Co. v. Gilligan ${ }^{64}$ was an early, if not the earliest, case to be decided under section 3176 of the Revised Statutes, as amended in 1916. In that case the taxpayer was engaged in manufacturing castings which were used by others in the manufacture of three-inch shrapnel shells. It had filed a late return and brought suit against the collector to recover certain munitions taxes and penalties which it had paid under protest. Evidence was offered that it believed in good faith that it was not required to pay the tax and that it was so advised by reputable counsel. On those facts and under a contemporary

58. Estate of Arthur D. Cronin, 7 T. C. 1403, 1413 (1946), modified on other issues, 164 F. 2d 561 (6th Cir. 1947); Eagle Piece Dye Works, 10 B. T. A. 1360, 1368 (1928).

59. Frischkorn Development Co., 30 B. T. A. 8, 14 (1934), aff'd on other issues, 88 F. 2d 1009 (6th Cir. 1937); Rogers Hornsby, 26 B. T. A. 591, 593 (1932); Gus. V. Winston, 22 B. T. A. 1194, 1199 (1931).

60. Estate of Abraham Werbelovsky, 9 T. C. 689 (1947); Estate of Samuel Goldstein, P-H 1947 TC Men. Dec. SERv. I 47,220 (1947); Malcolm Clifton Davenport, 6 T. C. 62, 67 (1946); see Estate of Charles Curie, 4 T. C. 1175, 1184 (1945).

61. George S. Groves, 38 B. T. A. 727, 738 (1938); American Milk Products Corp. v. United States, 41 F. 2 d 966 (Ct. Cl. 1930) ; but see Carnie-Goudie Mfg. Co., 18 B. T. A. 893, 900 (1930), rev'd on other issues, 24 B. T. A. 679 (1931), followed Bouvelt Realty, Inc., 46 B. T. A. 45, 48 (1942) (oversight of agents is reasonable cause). Cf. Paul E. Reinhold, P-H 1948 TC Mear. Dec. Serv. đ 48,196 (1948). In the Camiie-Goudie case the Board said there was no willful neglect and did not consider whether the delay was due to reasonable cause.

62. Pioneer Automobile Service Co., 36 B. T. A. 213, 221 (1937) ; Axel Holmstrom, 35 B. T. A. 1092, 1105 (1937).

63. 59 F. 2d 996 (2d Cir. 1932), affirming P-H 1931 B. T. A. Men. Dec. Serv. II 31,063 cert. dernied, 287 U. S. 642 (1932).

64. 281 Fed. 709 (6th Cir. 1922). 
Treasury ruling ${ }^{65}$ the court relieved the taxpayer from the penalties. The court said in part: ${ }^{\circ 6}$

The attendant and surrounding circumstances of this case have no tendency whatever to cast a doubt or suspicion upon the good faith of the taxpayer. While the fact that it sought and obtained legal advice, in and of itself, might not be sufficient to excuse its failure to file this return, nevertheless it tends to show that the taxpayer was acting in good faith and availed itself of the best means at its command to determine, honestly and fairly, the question of its liability. That counsel was mistaken in the advice given to the taxpayer is not at all surprising . . . [citing conflicting decisions]. It would therefore appear that the officers of this company were honestly mistaken as to its liability to pay this tax and that under the order of the Treasury Department above referred to, in the absence of circumstances having a tendency to cast doubt and suspicion upon its good faith, its ignorance of its liability to pay this tax is sufficient to constitute a reasonable cause for failure to make and file a return within the time prescribed by law.

The Dayton case is often cited but the reasoning used by the Court is no longer followed. The advice of counsel was treated in that case merely as evidence of the taxpayer's good faith. The court implied that ignorance of liability, coupled with good faith, was suffcient to constitute reasonable cause for delinquency. It is clear from later cases that a taxpayer may be ignorant of the law, in good faith, and yet have no reasonable cause for failure to file a required return. Nevertheless a general requirement of good faith has been kept alive in the cases.

The modern reasoning is best illustrated by a recent Circuit Court opinion in Hatfried, Inc. v. Commissioner, ${ }^{67}$ which reversed a Tax Court finding and decision. Hatfried, Inc., owned a hotel in Florida which it rented to its sole stockholder and from which it derived its entire gross income. No dividends were paid during the taxable year. All tax returns were prepared and filed by a certified public accountant. He was advised of the facts and circumstances surrounding the lease

65. L. 0.818, 1 CuMr. Bull. 247 (1919), which provided as follows: "Where the attendant and surrounding circumstances have a tendency to cast doubt and suspicion upon a taxpayer, a plea of mere ignorance is not sufficient to constitute a reasonable cause for failure to make and file a return within time prescribed by law for the purpose of being relieved of the penalty."

66. 281 Fed. 709, 712 (6th Cir. 1922).

67. 162 F. 2d 628 (3rd Cir. 1947), reversing P-H 1946 TC MEM. DEC. SERV. If 46,037 (1946) (on penalty issue). The advice of an account in the Hatfried case was treated by the circuit court as the basis of the taxpayer's belief that no return was required; in the Dayton case the advice of an attorney was treated merely as evidence of the taxpayer's good faith. In the Hatfried case ignorance of the law was regarded as immaterial where the taxpayer had relied upon a competent advisor; in the Dayton case ignorance of law was coupled with good faith to provide the basis for relief from penalty. 
but he "never suggested the filing of a personal holding company surtax return and none was filed." The income and declared value excess profits tax return was in evidence. It showed that the taxpayer's voting stock was owned by one person but it did not show that the taxpayer's rental income was received from its sole stockholder. The Tax Court held that the taxpayer was a personal holding company under the statute, that its rental income was personal holding company income within the meaning of section $502(f)$ of the Code. It further found and held that there was no reasonable cause for the failure to file a personal holding company surtax return. It said that the evidence was too meager to establish the reasonable cause sufficient to relieve the taxpayer from penalty for such delinquency. The Third Circuit Court affirmed the imposition of the tax but lifted the penalty. On the latter issue it held that the Tax Court's finding was without substantial basis in the evidence and that the meaning of section 291 had been misinterpreted. The circuit court said that the preparation of the income tax return by the accountant and the statements made therein showed that the taxpayer had been advised by the accountant and had relied upon his advice in failing to file a personal holding company surtax return. One judge dissented on the ground that the question of reliance was one of fact which should be determined by the Tax Court. But he agreed with the majority proposition that "the taxpayer who presents his facts to a lawyer or certified public accountant and relies on the advice given him by either one of these persons has proved that he has acted with reasonable cause and has negatived the charge of wilful neglect." 68

The real significance of the Hatfried case lies in the fact, assumed by the Circuit Court, that the taxpayer was advised by an accountant in ignorance of the law. The Government contended that ignorance of the law is no excuse, whether the ignorance is the fault of the taxpayer or his advisor. Apparently there was no evidence that the accountant had made any effort to acquaint himself with the personal holding company law. The Circuit Court implied that such evidence would be immaterial under the circumstances. It expressly repudiated the view that taxpayers should be held liable for the conduct of lawyers. or accountants who are entrusted with the duty of preparing their tax returns. The court rested its decision on the theory that Hatfried, Inc., had, in fact and law, exercised such ordinary business care and prudence as to constitute reasonable cause for its delinquency. The rationale of the decision is revealed by the following extracts from the opinion: ${ }^{68}$

68. 162 F. 2d 628, 635 (3rd Cir. 1947).

69. Id. at $632-635$. 
We approach the problem, whether there was any substantial basis for the Tax Court's finding, with these principles in mind: (1) "Reasonable cause means nothing more than' the exercise of ordinary business care and prudence." Southeastern Finance Co. v. Commissioner, 5 Cir., 153 F. 2d 205; Girard Inv. Co. v. Commissioner, supra, 122 F. $2 \mathrm{~d}$ at page 848. and (2) the penalties imposed under the revenue laws were designed to attach to conduct of a taxpayer "which is intentional, or knowing, or voluntary, as distinguished from accidental" (United States $v$. Murdock, 290 U. S. 389, 394, 54 S. Ct. 223, 225, 78 L. Ed. 381) as evidenced by the words in Section 291 "and not due to willful neglect."

The Courts, as above stated, have ruled that "reasonable cause means nothing more than the exercise of ordinary business care and prudence" and "willful" as "intentional, or knowing or voluntary."

To hold that a taxpayer who selects as his agent a certified public accountant (to whom as a class the Treasury Department and the Tax Court itself accord recognition as "experts" and as "counsel") has failed to exercise "ordinary business care and prudence" and becomes liable for the error of his advisor as "agent" is an inconceivable proposition.

It is evident from the foregoing that (1) the finding that there was no "reasonable cause" was without "substantial basis"; and (2) the Tax Court erred as a matter of law in the interpretation of the legal content of the words "reasonable cause" and "willful neglect" as used in Section 291.

The court concluded that good faith was shown by the fact that the taxpayer had made a full disclosure of the facts to its accountant. It thereby distinguished Tarbox Corporation, ${ }^{70}$ a case in which the Tax Court had approved a delinquency penalty. In this case the income tax return of a personal holding company, prepared by an accountant, contained statements which were contrary to fact. Such statements naturally raised a doubt whether sufficient information was made available to the accountant to enable him to give intelligent advice. The court said it was difficult to determine whether the taxpayer's failure to file the return was due to the fact that its advisor had "insufficient" information or was "unfamiliar" with the requirements of the taxing statute. It held that neither was sufficient excuse. The Hatfried case is clearly in conflict with the implication of the

70. 6 T. C. 35 (1946). Cf. Beam v. Hamilton, 289 Fed. 9 (6th Cir. 1923); The 1040 Springfield Ave. Corp., P-H 1949 TC Menr. Dec. Serv. II 49,065 (1949) Baynard Co., P-H 1942 B. T. A. MEM. DEC. SERv. II 42,395 (1942), remanded, 135 F. 2 d 43 (5th Cir. 1943); Jupiter Oil Co., P-H 1939 B. T. A. Mem. Dec. Serv. ก 39,523 (1939). 
latter point, i. e., that the taxpayer should be responsible for a reputable advisor's ignorance of law.

The court further (and erroneously) ${ }^{71}$ concluded that the accountant had made a full disclosure of the facts to the Commissioner through the statements made in the Hatfried income tax return. However, the Supreme Court held in Commissioner v. Lane-Wells Co. ${ }^{72}$ that the filing of corporate income tax returns did not satisfy the requirement of filing separate personal holding company surtax returns. Moreover, although the income tax returns did not disclose the taxpayer's status to the Commissioner, the Court remanded the case for a finding on the subject of reasonable cause for the failure to file the holding company returns. Therefore, it seems clear that neither the disclosure, nor non-disclosure, of facts to the Commissioner is important for purposes of relief from delinquency penalties. ${ }^{73}$ On the other hand, the failure to disclose facts to an advisor is relevant for the purpose of discrediting the basis of the taxpayer's alleged belief that no return was required.

The Hatfried case was followed in Orient Investment \& Finance Co., Inc. v. Commissioner, ${ }^{74}$ which also reversed a decision of the Tax Court on substantially similar facts. The evidence was more complete in this case, however, because it showed that the taxpayer had in fact relied upon its accountants for advice. Nothing was withheld from the accountants. On the other hand, the Commissioner lacked notice of all the facts. The reversals in the Hatfried and Orient cases restored these cases to the growing list of decisions which have given relief from delinquency penalties to taxpayers who had in fact relied upon advisors in failing to file required returns. ${ }^{75}$ Following the

71. The Hatfried income tax return did not show that its rental income was received from its sole stockholder, upon which fact the principal issue was decided against the taxpayer. See 1040 Springfield Ave. Corp., note 70 supra at n. 3.

72. 321 U. S. 219 (1944).

73. The Tax Court took a contrary view in Hermax Co., 11 T. C. 442 (1948), af'd per curiam, 175 F. $2 \mathrm{~d} 776$ (3rd Cir. 1949). See also 1040 Springfield Ave., P-H 1949 TC Mem. Dec. SERv. \49,065 (1949).

74. 166 F. 2d 601 (D. C. Cir. 1948), reversing P-H 1946 TC MEar. Dec. SERv. $\mathbb{I} 46,297$ (1947) (on penalty issue).

75. E. g., Keokuk \& Hamilton Bridge, Inc., P-H 1949 TC MEMr. Dec. SERv. II 49,119 (1949), modifying 12 T. C. 249 (1949); Estate of Wong Goo Shee, P-H 1948 TC Men. Dec. Serv. $\int 48,258$ (1948); Walnut St. Co. v. Glenn, 83 F. Supp. 945 (D. Ky. 1949) (tax consultant); Raymep Realty Corp., P-H 1948 TC MEAr. DEC. SERV. I 48,069 (1948) (accountant); Garret Holding Corp., 9 T. C. 1029, 1036 (1947) (attorney); Brooklyn \& Richmond Ferry Co., Inc., 9 T. C. 865, 876 (1947), .aff'd, 171 F. 2d 616 (2d Cir. 1948), cert. denied, - U. S. - (1949) (accountant); Dianna McFaddin Houk, P-H 1947 TC MEMr. Dec. SERv. II 47,180 (1947), rev'd on other issue, 173 F. 2d 821 (5th Cir. 1949) (attorney); Frederick Smith Enterprise Co. P-H 1947 TC MEM. DEC. SERv. If 47,148 (1947) aff'd, 167 F. 2d 356 (6th Cir. 1948) (accountant); Safety Tube Corporation, 8 T. C. 757, 766 (1947), aff'd, 168 F. 2d 787 (6th Cir. 1948) (attorney); William H. Gross, 7 T. C. 837, 848 (1946) (attorney) ; Barg's Bottling Co., P-H 1946 TC MEM. DEC. SERV. If 46,150 (1946) ( tax counsel) ; C. R. Lindback Foundation, 4 T. C. 652,667 (1945), aff'd, 150 F. 2d 986 (3rd Cir. 1945). (attorney); Three States Lumber Co., P-H 1945 TC MEM. 
reversals in the Hatfried and Orient cases the Tax Court said in Raymep Realty Corp., Inc.: ${ }^{76}$ "It now seems settled law that bona fide reliance by a taxpayer on the advice of a licensed accountant, such as occurred herein, amounts to the exercise of such ordinary business prudence as to constitute reasonable cause for failure to file a return."

The advisor in the Raymep case was a certified public accountant. In a prior case, Brooklyn \& Richmond Ferry Co., ${ }^{77}$ the advisor was an accountant whose qualifications were conceded at the hearing. The Tax Court cited the Hatfried case with approval in both cases. However, the Hatfried case was distinguished by the Tax Court in Hermax Co., Inc. ${ }^{78}$ recently affirmed per curiam by the same Circuit Court which had reversed the Tax Court in the Hatfried case. The Tax Court said the distinction was that Hermax Co., a personal holding company, had not disclosed the pertinent facts in its income tax return. $^{79}$ However, the basic distinction between these cases appears to be that Hatfried, Inc. employed a certified public accountant,

Dec. SeRv. $\{45,311$ (1945), rez'd on other grounds, 158 F. 2d 61 (7th Cir. 1946) (tax advisor); Bond Auto Loan Corp., P-H 1944 TC MEM. DEC. SERv. II 44,318 (1944), aff'd, 153 F. 2d 50 (8th Cir. 1946) (attorney); Citizens Mutual Investment Assn., P-H 1943 TC MEM. DEC. SERV. $\llbracket 43,257$ (1943), rehearing, 46 B. T. A. 48 (1942) (attorney and auditor); Wonderland Club, Inc., P-H 1942 BTA MÉr. DEc. SeRv. II 42,523 (1942) (accountant); Essex Loan Trust, P-H 1942 BTA MEM. DEC. SERV. \42,287 (1942) (accountant and attorney); Agricultural Securities Corp., 39 B. T. A. 1103, 1105 (1939); aff'd, 116 F. 2d 800 (9th Cir. 1941) (tax consultant); Adelaide Park Land, 25 B. T. A. 211, 212 (1932) (tax advisor); Adelaide McColgan, Admx., 10 B. T. A. 958, 960 (1928), dismissed (9th Cir. 1930) (attorney); Dayton Bronze Bearing Co. v. Gilligan, 281 Fed. 709 (6th Cir. 1922) (attorney); Contra: United States v. Archer, Adm., 174 F. $2 d 353$ (1st Cir. 1949), reversing 77 F. Supp. 919 (D. Mass. 1948) (attorney); Rodney, Inc. v. Hoey, 53 F. Supp. 604 (D. N. Y. 1944) (attorney); Hanson \& Van Winkle Co., P-H 1944 TC MEM. DEc. SERv. fi 44,080 (1944) (accountant); Seaboard Loan \& Savings Assn., Inc., 45 B. T. A. 510,516 (1941) (accountant); Lone Pine Lawn Corp., 41 B." T. A. 638, 643 (1940), aff'd, 121 F. 2d 935 (2d Cir. 1941) (fiscal agent) ; J. S. F. Crayton, 11 B. T. A. 1375, 1377 (1928) (former dep. collector). In Bro-Jeff Theatres, Inc., P-H 945 TC MEM. DEC. SERv. If 45,385 (1945), the parties narrowed the issue to whether the "accountants had reasonable cause to believe that no return should be filed." See Credit Bureau of Greater N. Y., Inc., P-H 1946 TC MeM. DEc. SERv. $\{46,229$ (1946), aff'd, 162 F. 2d 7 (2d Cir. 1947) (attorney); Fides, A. G., 47 B. T. A. 280, 285 (1942), aff'd, 137 F. $2 d 731$ (4th Cir. 1943), cert. denied, 320 U. S. 797 (1944) (attorney). The Fides case was relied upon by the Government in the Hatfried appeal in support of its position that ignorance of the law is no excuse, whether it be the fault of the taxpayer or his advisor. There is no indication in the reports of either the Credit Bureau or the Fides cases that the advice of counsel had actually been given to, or relied upon by, the taxpayers. See also Haywood Lumber \& Mining Co., 12 T. C. 735 (1949) (accountant), aff'd, - F. 2d - (2d Cir. 1949); Genesee Valley Gas Co., 11 T. C. 184 (1948).

76. P-H 1948 TC MEM. DEC. SERv. \4 48,069 (1948).

77. 9 T. C. 865,876 (1947), aff'd 171 F. $2 d 616$ (2d Cir. 1948), cert. denied, 336 U. S. 968 (1949).

78. 11 T. C. 442 (1948), aff'd per curiam, 175 F. 2d 776 (3rd Cir. 1949).

79. The Tax Court also said that Tarbox Corporation, 6 T. C. 35 (1946), was controlling because "In that case, under comparable facts, we held that ignorance of the law cannot of itself be an excuse or constitute reasonable cause for failing to comply with it." Supra note 78 at 446 . However, the accountant in the Hermax case, unlike the accountant in the Tarbox case, was apparently familiar with the facts. To that extent the citation of the Tarbox case conflicts with the decision in the Hatfried case unless the latter case is restricted in its application to certified public accountants. 
whereas Hermax Co. employed a "public accountant" who was not qualified as a tax advisor. It is significant that the court made a detailed examination of the accountant's qualifications. Although he was admitted to practice before the Treasury Department, the Tax Court refused to recognize this as a qualification in itself. It raised questions concerning his "expert knowledge" in Federal tax law, as well as a question concerning the propriety of his giving advice. ${ }^{80}$

The conclusion to be drawn from the Hermax case is that taxpayers have the burden of showing the individual qualifications of their advisors. This case even leaves some doubt whether it is enough to show that the advisor was licensed as a certified public accountant. Nevertheless such proof should be sufficient under the Hatfried rule, which accords recognition to the qualifications of certified public accountants and attorneys ${ }^{81}$ as a class.

\section{ConcLuston}

Delinquency penalty issues are secondary issues in most cases; and taxpayers frequently fail to offer all the evidence necessary for relief from such penalties. No other factor has had more influence in shaping the pattern of the penalty cases than the failure to prove all the facts which show a reasonable cause for the delinquency. It is hoped that the foregoing discussion has outlined the burden of proof in such cases.

To summarize :

Taxpayers who assert their inability to file a required return must show that they exercised ordinary business care and prudence in attempting to file the return.

Taxpayers who believed that no return was required must show the basis for their belief and further show that it was reasonable.

The above rules also apply to delinquencies caused by taxpayers' agents.

80. The Tax Court said: "In passing, it may be questioned whether it was proper for them [the accountant and the 'tax man' in his firm] to give such advice. See In re Bermard Bercu, New York Supreme Court, Appellate Division, First Department, No. 161, April 12, 1948." Note 78 supra at 497.

81. There are also close analogies in other fields of law. For example, the initiation of proceedings without probable cause is one of the elements of a cause of action for wrongful prosecution of criminal proceedings (malicious prosecution) or wrongful initiation of civil proceedings. In such cases the reliance upon the advice of reputable and disinterested counsel, sought in good faith after a full disclosure of the facts, is conclusive of the existence of probable cause. REsTatenrent, ToRTs $\$ \$ 666,675$ (1934). Cf. Restatentent, Property \$428, comment $k$ (1938). See RESTATEMENT, TRUSTs \$201, comment b (1935). In such cases, however, the advice of an attorney who made a contingent fee arrangement before the facts were submitted to him is the advice of an interested party and does not protect the client. Restatenent, Torts $\$ 675$, comment h (1934). 
Taxpayers who relied upon the advice of an attorney or accountant must show that all necessary facts were given in good faith to the advisor and that he was qualified to give tax advice.

Penalties for failure to file estate and gift tax returns may be avoided for reasonable cause only if late returns are ultimately filed by such taxpayers. The retention of this requirement for gift and estate taxes while omitting it for income taxes appears to have been an oversight on the part of the draftsmen of the Code. In any event, the Code should be amended to provide uniform conditions for relief from income, estate and gift tax delinquencies. 